\title{
IN SILICO STUDY OF CEPHALOSPORIN DERIVATIVES TO INHIBIT THE ACTIONS OF Pseudomonas aeruginosa
}

\section{Studi In Silico Senyawa Turunan Sefalosporin dalam Menghambat Aktivitas Bakteri Pseudomonas aeruginosa}

\author{
Saly Amaliacahya Aprilian*, Firdayani, Susi Kusumaningrum \\ Pusat Teknologi Farmasi dan Medika, BPPT, Gedung LAPTIAB 610-612 Kawasan Puspiptek, Setu, \\ Tangerang Selatan, Banten 15314 \\ *Email: saly.amaliacahya@bppt.go.id
}

\begin{abstract}
ABSTRAK
Infeksi yang diakibatkan oleh bakteri gram-negatif, seperti Pseudomonas aeruginosa telah menyebar luas di seluruh dunia. Hal ini menjadi ancaman terhadap kesehatan masyarakat karena merupakan bakteri yang multi-drug resistance dan sulit diobati. Oleh karena itu, pentingnya pengembangan agen antimikroba untuk mengobati infeksi semakin meningkat dan salah satu yang saat ini banyak dikembangkan adalah senyawa turunan sefalosporin. Penelitian ini melakukan studi mengenai interaksi tiga dimensi (3D) antara antibiotik dari senyawa turunan Sefalosporin dengan penicillin-binding proteins (PBPs) pada $\mathrm{P}$. aeruginosa. Tujuan dari penelitian ini adalah untuk mengklarifikasi bahwa agen antimikroba yang berasal dari senyawa turunan sefalosporin efektif untuk menghambat aktivitas bakteri P. aeruginosa. Struktur PBPs didapatkan dari Protein Data Bank (PDB ID: 5DF9). Sketsa struktur turunan sefalosporin digambar menggunakan Marvins Sketch. Kemudian, studi mengenai interaksi antara antibiotik dan PBPs dilakukan menggunakan program Mollegro Virtual Docker 6.0. Hasil yang didapatkan yaitu nilai rerank score terendah dari kelima generasi sefalosporin, di antaranya sefalotin (-116.306), sefotetan (-133.605), sefoperazon (-160.805), sefpirom (144.045), dan seftarolin fosamil (-146.398).
\end{abstract}

Keywords: antibiotik, penicillin-binding proteins, P. aeruginosa, sefalosporin, studi interaksi

\begin{abstract}
Infections caused by gram-negative bacteria, such as Pseudomonas aeruginosa, have been spreading worldwide. It is a threat to public health because of its multi-drug resistance and difficulty to treat. Therefore, the demand for developing antimicrobial agents to treat infections is increasing. One of them that is currently under development is cephalosporin derivative compounds. This research studied the three-dimensional (3D) interaction between antibiotics from cephalosporin derivatives and penicillin-binding proteins (PBPs) in $P$. aeruginosa. This study aimed to clarify whether the cephalosporin derivatives were effective in inhibiting the activity of $P$. aeruginosa. The PBPs structure was obtained from the Protein Data Bank (PDB ID: 5DF9). The structural sketch of the cephalosporin derivative was drawn using the Marvins Sketch, whereas the study on the interaction between antibiotics and PBPs was carried out using the Mollegro Virtual Docker 6.0 program. The results showed the lowest rerank score from five cephalosporin derivatives, namely cephalotin $(-116,306)$, cephotetan $(-133.605)$, cephoperazone (-160.805), cephpirome (-144.045), and cephtaroline fosamil (-146.398).
\end{abstract}

Kata Kunci: antibiotics, cephalosporins, interaction study, PBP, P. aeruginosa 


\section{INTRODUCTION}

Infectious diseases are one of the leading causes of morbidity and mortality, and a decrease in the productivity of people, especially in developing countries. They are caused by bacteria that occur in communities or hospitals (Ahrens and Pigeot 2014; Golwalla et al. 2017), and the use of antibiotics is very important in preventing and eliminating them. However, over $70 \%$ pathogenic bacteria have become more resistant to multiple types of antibiotics. Multidrug-resistant (MDR) bacteria formally referred to as "superbugs" are the major causes of infections because of failure to respond to conventional treatment (Pisano et al., 2019). Besides, the inappropriate use of antibiotics in medicine have made some serious infections become more difficult to treat (Abrigach et al. 2018).

Gram-negative pathogens are often responsible for the four most frequent types of hospital-acquired infection. They include pneumonia, intra-abdominal infection (IAI), urinary tract infection (UTI), and bloodstream infection (BSI) (Merchant et al., 2018). One of the types of gram-negative bacteria that is dangerous because of its nature is the Pseudomonas aeruginosa. Furthermore, the treatment of infections caused by these resistant bacteria requires a high potential antibiotic. $P$. aeruginosa which is also referred to as an opportunistic pathogen which uses the damage of its host defense mechanism to initiate an infection. This type of bacteria adapts to challenging environments such as in the damaged lung of cystic fibrosis patients and also to the problems of the immune system and antibiotics treatment (Hogardt and Heesemann 2011, Brao et al., 2020).

The cell wall is an important structure for bacterial survival (An et al. 2015) and the membrane-binding enzyme involved in the final stages of bacterial cell wall synthesis is the Penicillin-binding Protein (PBP) (Sainsbury et al. 2011; An et al. 2015). These proteins are grouped based on their conserved domain structure and molecular weight (Kocaoglu et al. 2015). PBPs have been studied for a long period of time and have been chosen as the highly successful $\beta$ lactam antibiotics target (Macheboeuf et al. 2006). These antibiotics exert their antibacterial effect through covalent interactions with PBPs, thereby blocking the terminal step in cell wall biosynthesis (Kosowska-Shick et al. 2010). The levels of expression of PBPs differ between $\beta$-lactam resistant bacterial strains. However, this variation does not appear to be linked with the resistance development (Ren et al., 2016).

An example of an antibiotic that has the activity of inhibiting the growth of these bacteria is the Cephalosporin derivatives which are betalactam antibiotic that inhibits the synthesis of bacterial cell walls. Currently, there have been five generations of Cephalosporin derivatives that are active against gram-positive and gram-negative bacteria (Masoud et al. 2014). However, it is necessary to carry out further studies in order to determine the most potent antibiotic activity against $P$. aeruginosa.

Molecular docking study could be used to model the interaction of a small molecule and protein at the atomic level. Furthermore, it is used in characterizing the behaviour of small molecules' at the binding site of target proteins and to elucidate fundamental biochemical processes (Meng et al. 2011). The definition of molecular docking is an optimization problem which describes the "best fit" orientation of a ligand that binds to a particular protein of interest. The Modes of Binding are several possible mutual conformations in which binding occur (Vijesh et al. 2013). Docking is an important tool in pharmaceutical research which requires a program that is based on a different algorithm. This technique is not a stand-alone method and requires the workflow of various experimental techniques in silico (Meng et al. 2011). Therefore, the aim of this study is to confirm the antimicrobial compounds from the cephalosporins generation that are effective in inhibiting the action of $P$. aeruginosa.

\section{MATERIALS AND METHODS}

This study was performed at the design and modelling laboratory in Centre of Pharmaceutical and Medical Technology BPPT (coordinates: -6.3572656, 106.6658068). Furthermore, the crystal structure of Penicillin-binding proteins (PBPs) was obtained from the Protein Data Bank (PDB ID: 5DF9). It was penicillin-binding protein 3 (PBP3) from $P$. aeruginosa that was 
the molecular target of $\beta$-lactam based antibiotics(Berman et al. 2000; Kumar et al. 2014). The compounds were obtained from the study conducted by Masoud et al., (Masoud et al. 2014) and were the derivatives of cephalosporin from the first generation to the fifth generation. Cephalosporins are relatively nontoxic group of antibiotics (Gad 2014; Han et al. 2018) and are also one of the most frequently prescribed drugs. This is due to their wide-range and generally tolerated clinical uses, with approximately $1-3 \%$ of the population reporting cephalosporin allergies (Chaudhry et al. 2019). The 2D structures of ligands were drawn using Marvin Sketch 19.16 and conformed into 3D structures. Furthermore, the 3D structure of ligand molecules were constructed, optimized, and converted into Mol2 file format (Lee and Jones 2018) of which the lowest energy structure was chosen. Docking simulation between antibiotics and PBPs were performed using the Mollegro Virtual Docker 6.0 program (Thomsen and Christensen 2006).

\section{Docking studies}

The structure of PBPs was obtained from the Protein Data Bank (Kumar et al. 2014) (http://www.rcsb.org) with a resolution of $2.7 \AA$. These studies were carried out to get the docking score and the interaction between cephalosporin derivative antibiotics with PBPs of bacteria. Validation method was conducted by extracting the ligands that were already present in the proteins before performing the docking processes (Firdayani et al. 2018). The programs that were able to return poses below a pre-selected Root Mean Square Deviation (RMSD) value from the known conformation (usually 1.5 or $2 \AA$ depending on ligand size) were considered to have performed successfully (Hevener et al. 2009). The docking method was performed on the PBPs ligand in the coordinates with $x$, $y, z$ values, namely $-42.95 ;-9.10 ;-39.07$ and radius $15 \AA$ respectively. The docking parameter of the system was the grid resolution with $0.30 \AA$, using the MolDock SE algorithm with 10 number of runs. Maximum iterations used in this system was 1500 with a maximum population size of 50 . Furthermore, after the docking of the PBPs ligand was carried out, that of the antibiotics molecule was then inserted into the system.

\section{RESULT AND DISCUSSION}

Taking coordinate space samples from the target binding site and assessing any possible ligand poses within these sites was required in the docking process. The RMSD value which is less than two indicates that this method was valid. Furthermore, the RMSD value that was obtained from this simulation was 0.99466 . The structure from before and after molecular docking (MD) is shown in Figure 1.

The best binding poses for each ligand of antibiotics molecule were the those that had the lowest binding energy which are represented by negative docking scores. Furthermore, the result of the docking scores were analyzed into Table 1.

The rerank score is a parameter that is often used to analyze the interaction between a drug and its receptor because it is more complete than the Moldock score. It is a linear combination of the E-inter between ligand and protein and the E-intra from the ligand (Singh et al. 2016). The data revealed that the cephalosporin derivatives had antibiotic effect against $P$. aeruginosa that were represented by the negative values of rerank score. Furthermore, the lowest rerank scores from the first generation to the fifth generation, include cephalotin (-116.306), cefotetan (133.605), cefoperazone (-160.805), cefpirome (-144.045), and ceftarolinefosamil $(-146.398)$. The hydrogen bond interactions between the antibiotics and PBPs of $P$. aeruginosa are shown in Figure 2.

Our data revealed that cefoperazone was the best antibiotic against Pseudomonas aeruginosa which was used in this study with a rerank score of -160.805 . The relationship with the residue of the lower rerank score

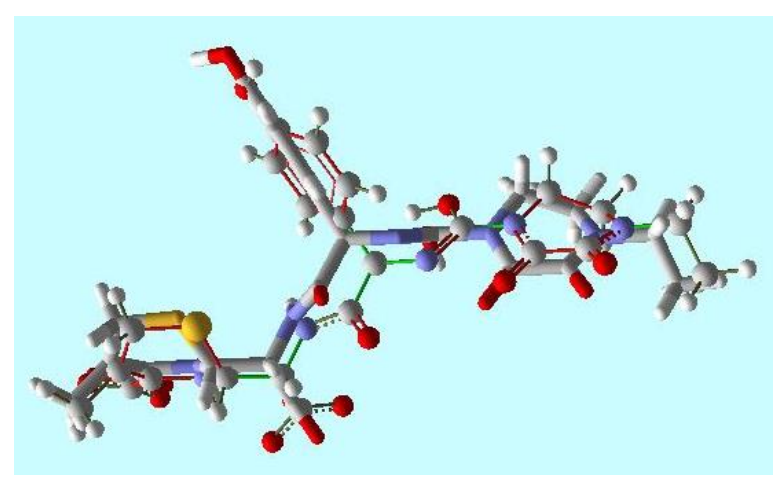

Figure 1. Redocking position of reference ligand in Penicillin-binding Proteins (PBPs) 
Table 1. Molecular docking result

\begin{tabular}{|c|c|c|c|c|c|}
\hline Generation & Ligand & $\begin{array}{l}\text { MolDock } \\
\text { Score }\end{array}$ & $\begin{array}{l}\text { Rerank } \\
\text { Score }\end{array}$ & HBond & Interaction \\
\hline \multirow[t]{8}{*}{ First } & Cephalotin & -144.592 & -116.306 & -12.6475 & $\begin{array}{l}\text { Ser294, Thr487, } \\
\text { Ser485 }\end{array}$ \\
\hline & Cefaloridine & -138.571 & -116.276 & -8.26248 & $\begin{array}{l}\text { Lys484, Ser349, } \\
\text { Ser294, Thr487 }\end{array}$ \\
\hline & Cefazolin & -138.787 & -113.67 & -12.3866 & $\begin{array}{l}\text { Gly535, Thr487, } \\
\text { Ser485, Gly534 }\end{array}$ \\
\hline & Cefapirin & -137.94 & -109.759 & -17.9191 & $\begin{array}{l}\text { Tyr409, Thr487, } \\
\text { Asn351, Ser349, } \\
\text { Ser294 }\end{array}$ \\
\hline & Cefroxadine & -115.849 & -104.879 & -11.5072 & $\begin{array}{l}\text { Tyr409, Thr487, } \\
\text { Ser294, Ser349 }\end{array}$ \\
\hline & Cefradine & -111.313 & -101.25 & -11.8415 & $\begin{array}{l}\text { Tyr409, Thr487, } \\
\text { Ser349, Ser294 }\end{array}$ \\
\hline & Cefadroxil & -112.962 & -101.241 & -16.7688 & $\begin{array}{l}\text { Ser349, Asn351, } \\
\text { Thr487, Arg331, } \\
\text { Tyr407, Tyr409 }\end{array}$ \\
\hline & Cephalexin & -105.981 & -91.8439 & -10.4703 & $\begin{array}{l}\text { Arg331, Thr329, } \\
\text { Tyr409, Arg489, } \\
\text { Asn351 }\end{array}$ \\
\hline \multirow[t]{11}{*}{ Second } & Cefotetan & -164.679 & -133.605 & -11.0131 & $\begin{array}{l}\text { Arg489, Thr329, } \\
\text { Tyr409, Asn351, } \\
\text { Gly535, Ser485, } \\
\text { Thr487, Ser349, } \\
\text { Ser294 }\end{array}$ \\
\hline & Cefotiam & -154.443 & -124.411 & -11.7498 & $\begin{array}{l}\text { lle347, Thr487, } \\
\text { Arg331, Arg489, } \\
\text { Tyr409 }\end{array}$ \\
\hline & Cefminox & -143.174 & -124.375 & -18.4823 & $\begin{array}{l}\text { Arg489, Ser485, } \\
\text { Ser349, Lys484, } \\
\text { Ser294, Asn351, } \\
\text { Thr487, Tyr409, } \\
\text { Tyr407 }\end{array}$ \\
\hline & Cefamandole & -149.519 & -123.774 & -22.7464 & $\begin{array}{l}\text { Asn351, Ser349, } \\
\text { Ser294, Thr487, } \\
\text { Ser485, Gly535 }\end{array}$ \\
\hline & Cefonicid & -152.638 & -123.628 & -16.5122 & $\begin{array}{l}\text { Ile347, Ser334, } \\
\text { Val333, Thr487, } \\
\text { Ser349, Ser294, } \\
\text { Tyr409, Arg 489 }\end{array}$ \\
\hline & Cefoxitin & -136.803 & -118.587 & -14.7191 & $\begin{array}{l}\text { Ser485, Tyr409, } \\
\text { Ser294, Thr487, } \\
\text { Ser349 }\end{array}$ \\
\hline & Cefuroxime & -138.464 & -114.255 & -9.40136 & $\begin{array}{l}\text { Arg489, Tyr409, } \\
\text { Thr487, Asn351 }\end{array}$ \\
\hline & Ceforanide & -154.466 & -113.816 & -7.40938 & $\begin{array}{l}\text { Arg331, Arg489, } \\
\text { Asn351 }\end{array}$ \\
\hline & Cefmetazole & -138.425 & -112.959 & -10.6955 & $\begin{array}{l}\text { Thr487, Tyr409, } \\
\text { Arg489, Ser349, } \\
\text { Ser294 }\end{array}$ \\
\hline & Cefprozil & -110.591 & -102.499 & -8.18848 & $\begin{array}{l}\text { Ser349, Ser294, } \\
\text { Tyr409 }\end{array}$ \\
\hline & Cefaclor & -109.995 & -100.268 & -18.5491 & $\begin{array}{l}\text { Tyr409, Thr487, } \\
\text { Ser249, Ser485, } \\
\text { Ser349, Lys484, } \\
\text { Asn351 }\end{array}$ \\
\hline
\end{tabular}


Table 1. Molecular docking result (continued)

\begin{tabular}{|c|c|c|c|c|c|}
\hline Generation & Ligand & $\begin{array}{l}\text { MolDock } \\
\text { Score }\end{array}$ & $\begin{array}{l}\text { Rerank } \\
\text { Score }\end{array}$ & HBond & Interaction \\
\hline Second & Loracarbef & -112.341 & -97.6982 & -12.9883 & $\begin{array}{l}\text { Thr487, Asn351, } \\
\text { Ser294, Ser485, } \\
\text { Ser349 }\end{array}$ \\
\hline \multirow[t]{14}{*}{ Third } & Cefoperazone & -194.788 & -160.805 & -24.9446 & $\begin{array}{l}\text { Arg489, Tyr409, } \\
\text { Tyr407, Arg331 }\end{array}$ \\
\hline & Cefsulodin & -173.407 & -139.393 & -14.619 & $\begin{array}{l}\text { Thr487, Ser349, } \\
\text { Ser294, Ser485 }\end{array}$ \\
\hline & Cefodizime & -167.642 & -135.185 & -15.7511 & $\begin{array}{l}\text { Tyr409, Ser294, } \\
\text { Arg489, Thr487, } \\
\text { Arg331, Arg499 }\end{array}$ \\
\hline & Ceftazidime & -157.452 & -127.854 & -8.60214 & $\begin{array}{l}\text { Tyr409, Arg489, } \\
\text { Asn351, Tyr407 }\end{array}$ \\
\hline & Cefotaxime & -151.61 & -125.827 & -17.8636 & $\begin{array}{l}\text { Arg489, Ser485, } \\
\text { Ser294, Lys484, } \\
\text { Ser349, Thr487, } \\
\text { Asn351, Tyr409 }\end{array}$ \\
\hline & Cefditoren & -157.005 & -124.507 & -10.4001 & $\begin{array}{l}\text { Asn351, Ser334, } \\
\text { Ser349, Ser294, } \\
\text { Thr487, Tyr409 }\end{array}$ \\
\hline & Ceftiofur & -164.475 & -124.036 & -13.2387 & $\begin{array}{l}\text { Ser294, Arg489, } \\
\text { Thr487, Tyr409, } \\
\text { Ser349, Ser485 }\end{array}$ \\
\hline & Ceftriaxone & -165.97 & -124.033 & -8.93295 & Tyr407, Arg489 \\
\hline & Cefixime & -156.815 & -123.404 & -21.9007 & $\begin{array}{l}\text { Tyr532, Arg489, } \\
\text { Tyr409, Ser349, } \\
\text { Lys484, Ser294, } \\
\text { Thr487, Asn351 }\end{array}$ \\
\hline & Cefpodoxime & -143.688 & -120.741 & -12.2727 & $\begin{array}{l}\text { Thr487, Tyr409, } \\
\text { Asn351, Arg489 }\end{array}$ \\
\hline & Ceftibuten & -140.812 & -118.684 & -13.1578 & $\begin{array}{l}\text { Asn351, Ser349, } \\
\text { Ser294, Ser485, } \\
\text { Thr487 }\end{array}$ \\
\hline & Cefetamet & -133.743 & -116.248 & -13.9804 & $\begin{array}{l}\text { Ser485, Thr487, } \\
\text { Ser294, Ser349, } \\
\text { Tyr409, Arg489 }\end{array}$ \\
\hline & Ceftizoxime & -134.105 & -111.873 & -17.0225 & $\begin{array}{l}\text { Ser485, Arg489, } \\
\text { Tyr409, Thr487, } \\
\text { Asn351, Ser294, } \\
\text { Ser349 }\end{array}$ \\
\hline & Cefdinir & -122.104 & -111.17 & -15.1259 & $\begin{array}{l}\text { Arg489, Ser294, } \\
\text { Ser349, Ser485, } \\
\text { Asn351, Thr487 }\end{array}$ \\
\hline \multirow[t]{3}{*}{ Fourth } & Cefpirome & -173.913 & -144.045 & -11.7015 & $\begin{array}{l}\text { Asn351, Tyr409, } \\
\text { Ser294, Thr487, } \\
\text { Gly535, Gly534, } \\
\text { Ser485 }\end{array}$ \\
\hline & Cefepime & -170.398 & -135.567 & -14.0559 & $\begin{array}{l}\text { Ser485, Ser349, } \\
\text { Ser294, Thr487, } \\
\text { Asn351, Tyr409 }\end{array}$ \\
\hline & Cefquinome & -149.411 & -120.689 & -9.39701 & $\begin{array}{l}\text { Asn351, Ser294, } \\
\text { Thr487, Ser349 }\end{array}$ \\
\hline \multirow[t]{2}{*}{ Fifth } & Ceftaroline Fosamil & -185.78 & -146.398 & -14.2219 & $\begin{array}{l}\text { Tyr407, Arg331, } \\
\text { Tyr503, Arg489, } \\
\text { Glu500 }\end{array}$ \\
\hline & Ceftobiprole & -166.403 & -136.283 & -7.71285 & $\begin{array}{l}\text { Ser294, Ser485, } \\
\text { Tyr407, Arg489, } \\
\text { Ser349, Thr487 }\end{array}$ \\
\hline
\end{tabular}



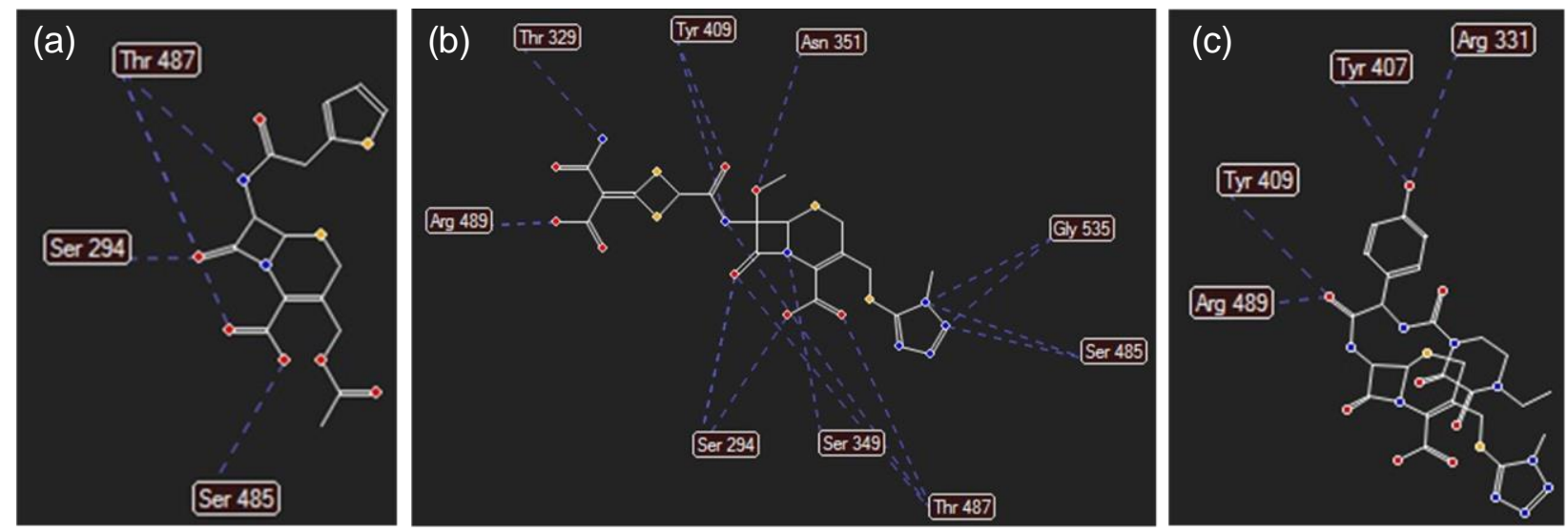

Figure 2. (a) Interactions of antibiotics with residue Cephalotin;

(b) Interactions of antibiotics with residue Cefotetan; (c) Interactions of antibiotics with residue Cefoperazone; (d) Interactions of antibiotics with residue Cefpirome; (e) Interactions of antibiotics with residue Ceftaroline fosamil
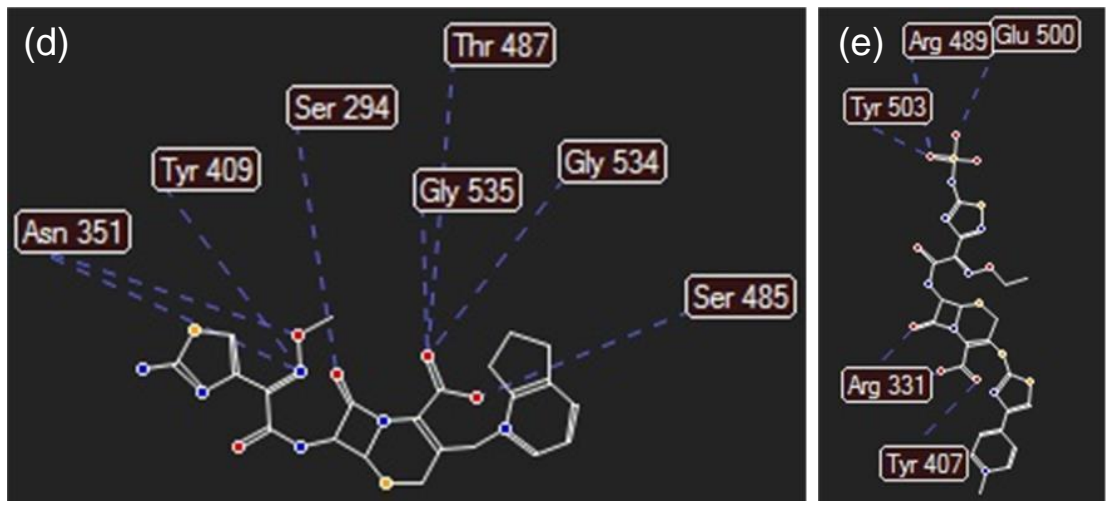

shows that the interaction between the drug and receptor is more stable. The hydrogen bonds of cefoperazone interaction with PBPs was with Arg489, Tyr409, Tyr407, Arg331. Based on the result, it was predicted that cefoperazone has good activity against PBPs of $P$. aeruginosa bacteria. This is in accordance with the study conducted by Ren et al.(2016) which states that cefoperazone is one of the few cephalosporins that are effective in treating Pseudomonas bacterial infections. However, cefoperazone could inhibit carbapenemresistant $P$. aeruginosa due to the MIC values, which are between the ranges of 4 to $64 \mu \mathrm{g} / \mathrm{mL}$ (Lai et al. 2019).

\section{CONCLUSION}

The molecular docking studies were performed to explore possible binding modes of cephalosporin derivatives into PBPs of bacteria. The study revealed that cephalosporin derivatives have good activity against bacteria especially the third generation. Furthermore, cefoperazone showed the lowest value of rerank score and was proven to be effective in inhibiting the actions of $P$. aeruginosa bacteria.

\section{AUTHORSHIP STATEMENT}

All authors had an equal contribution in conducting the research, preparing, and revising the manuscript.

\section{ACKNOWLEDGMENTS}

The authors would like to acknowledge that funding for this project came from the government program (INSINAS) by Ministry of Research, Technology, and Higher Education of the Republic of Indonesia.

\section{REFERENCES}

Abrigach F, Rokni Y, Takfaoui A, Khoutoul M, Doucet H, Asehraou A, Touzani R (2018) In vitro screening, homology modeling and molecular docking studies of some pyrazole and imidazole derivatives. Biomed Pharmacother 103: 653-661. doi: 10.1016/j.biopha.2018.04.061

Ahrens W, Pigeot I (2014) Handbook of Epidemiology. Second edition. Springer, New York. doi: 10.1007/978-0-387-09834-0 An YD, Du QZ, Tong LY, Yu ZW, Gong XW (2015) Cloning, expression and purification of penicillin-binding protein 3 from Pseudomonas aeruginosa 
CMCC 10104. Protein Expr Purif 110: 37-42. doi: 10.1016/j.pep.2014.12.004

Berman HM, Westbrook J, Feng Z, Gilliland $\mathrm{G}$, Bhat TN, Weissig $\mathrm{H}$, Shindyalov IN, Bourne PE (2000) The protein data bank. Nucleic Acids Res 28: 235-242. doi: 10.1093/nar/28.1.235

Brao KJ, Wille BP, Lieberman J, Ernst RK, Shirtliff ME, Harro JM (2020) Scnn1btransgenic BALB/C mice as a model of Pseudomonas aeruginosa infections of the cystic fibrosis lung. Infect Immun 88: e00237-20. doi: 10.1128/IAI.00237-20

Chaudhry SB, Veve MP, Wagner JL (2019) Cephalosporins: A focus on side chains and $\quad \beta$-lactam cross-reactivity. Pharmacy (Basel) 7: 103. doi: 10.3390/pharmacy7030103

Firdayani, Arsianti A, Churiyah, Yanuar A (2018) Molecular docking and dynamic simulation studies of benzoylated emodin into HBV core protein. J Young Pharm 10: S20-S24. doi: 10.5530/jyp.2018.2s.5

Gad SC (2014) Cephalosporins. In: Wexler P (ed) Encyclopedia Toxicology vol 1, 3rd edn. Elsevier, Amsterdam, pp 768-770

Golwalla S, Nadkar M, Golwalla SA (2017) Infectious Diseases and Infections. In: Nadkar MY (ed) Golwalla's Medicine for Students. The Health Sci Pub, New Delhi, pp 693-726. doi: 10.5005/jp/books/13059_11

Han Y, Zheng Y, Zhang J, Hu C (2018) Neurobehavioral effects of cephalosporins: Assessment of locomotors activity, motor and sensory development in zebrafish. Front Pharmacol 9: 160. doi: 10.3389/fphar.2018.00160

Hevener KE, Zhao W, Ball DM, Babaoglu K, Qi J, White SW, Lee RE (2009) Validation of molecular docking programs for virtual screening against dihydropteroate synthase. J Chem Inf Model 49: 444-460. doi: $10.1021 / \mathrm{ci800293n}$

Hogardt M, Heesemann J (2011) Microevolution of Pseudomonas aeruginosa to a chronic pathogen of the cystic fibrosis lung. In: Dobrindt $U$, Hacker J, Svanborg C (eds) Between Pathogenicity and Commensalism. Current Topics in Microbiology and Immunology Vol 358. Springer, Berlin, pp 91-118. doi: 10.1007/82_2011_199

Kocaoglu O, Tsui H-CT, Winkler ME, Carlson EE (2015) Profiling of $\beta$-lactam selectivity for penicillin-binding proteins in Streptococcus pneumoniae D39. Antimicrob Agents Chemother 59: 35483555. doi: 10.1128/AAC.05142-14

Kosowska-Shick K, McGhee PL, Appelbaum PC (2010) Affinity of ceftaroline and other $\beta$-lactams for penicillin-binding proteins from Staphylococcus aureus and Streptococcus pneumoniae. Antimicrob Agents Chemother 54: 16701677. doi: 10.1128/AAC.00019-10

Kumar KM, Anitha P, Sivasakthi V, Bag S, Lavanya $P$, Anbarasu A, Ramaiah $S$ (2014) In silico study on penicillin derivatives and cephalosporins for upper respiratory tract bacterial pathogens. 3 Biotech 4: 241-251. doi: 10.1007/s13205-013-0147-z

Lai CC, Chen CC, Lu YC, Chuang YC, Tang HJ (2019) In vitro activity of cefoperazone and cefoperazone-sulbactam against carbapenem- resistant Acinetobacter baumannii and Pseudomonas aeruginosa. Infect Drug Resist 12: 25-29. doi: 10.2147/IDR.S181201

Lee AC, Jones AL (2018) Multi-resistant Pseudomonas aeruginosa ST235 in cystic fibrosis. Paediatr Respir Rev 27: 18-20. doi: 10.1016/j.prrv.2018.05.009

Macheboeuf $\mathrm{P}$, Contreras-Martel C, Job V, Dideberg O, Dessen A (2006) Penicillin binding proteins: key players in bacterial cell cycle and drug resistance processes. FEMS Microbiol Rev 30: 673-691. doi: 10.1111/j.1574-6976.2006.00024.x

Masoud MS, Ali AE, Nasr NM (2014) Chemistry, classification, pharmacokinetics, clinical uses and analysis of beta lactam antibiotics: A review. J Chem Pharm Res 6: 28-58

Meng X-Y, Zhang H-X, Mezei M, Cui M (2011) Molecular docking: a powerful approach for structure-based drug discovery. Curr Comput Aided Drug Des 7: 146-157. doi: 10.2174/157340911795677602

Merchant S, Proudfoot EM, Quadri HN, McElroy HJ, Wright WR, Gupta A, Sarpong EM (2018) Risk factors for Pseudomonas aeruginosa infections in Asia-Pacific and consequences of inappropriate initial antimicrobial therapy: A systematic 
literature review and meta-analysis. J Glob Antimicrob Resist 14: 33-44. doi: 10.1016/j.jgar.2018.02.005

Pisano MB, Kumar A, Medda R, Gatto G, Pal R, Fais A, Era B, Cosentino S, Uriarte E, Santana L, Pintus F, Matos MJ (2019) Antibacterial activity and molecular docking studies of a selected series of hydroxy-3arylcoumarins. Molecules 24: 2815. doi: 10.3390/molecules24152815

Ren J, Nettleship JE, Males A, Stuart DI, Owens RJ (2016) Crystal structures of penicillin-binding protein 3 in complexes with azlocillin and cefoperazone in both acylated and deacylated forms. FEBS Lett 590: 288297. doi: 10.1002/1873-3468.12054

Sainsbury S, Bird L, Rao V, Shepherd SM, Stuart DI, Hunter WN, Owens RJ, Ren J (2011) Crystal structures of penicillin- binding protein 3 from Pseudomonas aeruginosa: Comparison of native and antibiotic-bound forms. J Mol Biol 405: 173-184. doi: 10.1016/j.jmb.2010.10.024 Singh SP, Deb CR, Ahmed SU, Saratchandra Y, Konwar BK (2016) Molecular docking simulation analysis of the interaction of dietary flavonols with heat shock protein 90. J Biomed Res 30: 67-74. doi: 10.7555/JBR.30.20130158

Thomsen R, Christensen MH (2006) MolDock: A new technique for highaccuracy molecular docking. J Med Chem 49: 3315-3321. doi: 10.1021/jm051197e

Vijesh AM, Isloor AM, Telkar S, Arulmoli T, Fun H-K (2013) Molecular docking studies of some new imidazole derivatives for antimicrobial properties. Arab J Chem 6: 197-204. doi: 10.1016/j.arabjc.2011.10.007 